\title{
Bacteriophage-Based Bacterial Wilt Biocontrol for an Environmentally Sustainable Agriculture
}

\author{
Belén Álvarez ${ }^{1}$ and Elena G. Biosca ${ }^{2 *}$ \\ ' Departamento de Investigación Aplicada y Extensión Agraria, Instituto Madrileño de Investigación y Desarrollo Rural, \\ Agrario y Alimentario, Madrid, Spain, ${ }^{2}$ Departamento de Microbiología y Ecología, Universitat de València, Valencia, Spain
}

\section{OPEN ACCESS}

Edited by:

Boshou Liao,

Oil Crops Research Institute (CAAS),

China

Reviewed by:

Zakira Naureen,

University of Nizwa, Oman

Munusamy Madhaiyan,

Temasek Life Sciences Laboratory,

Singapore

*Correspondence:

Elena G. Biosca

elena.biosca@uv.es

Specialty section:

This article was submitted to

Plant Microbe Interactions,

a section of the journal

Frontiers in Plant Science

Received: 10 April 2017

Accepted: 28 June 2017

Published: 14 July 2017

Citation:

Álvarez B and Biosca EG (2017)

Bacteriophage-Based Bacterial Wilt

Biocontrol for an Environmentally

Sustainable Agriculture.

Front. Plant Sci. 8:1218.

doi: 10.3389/fpls.2017.01218
Bacterial wilt diseases caused by Ralstonia solanacearum, R. pseudosolanacearum, and $R$. syzygii subsp. indonesiensis (former $R$. solanacearum species complex) are among the most important plant diseases worldwide, severely affecting a high number of crops and ornamentals. Difficulties of bacterial wilt control by non-biological methods are related to effectiveness, bacterial resistance and environmental impact. Alternatively, a great many biocontrol strategies have been carried out, with the advantage of being environmentally friendly. Advances in bacterial wilt biocontrol include an increasing interest in bacteriophage-based treatments as a promising re-emerging strategy. Bacteriophages against the bacterial wilt pathogens have been described with either lytic or lysogenic effect but, they were proved to be active against strains belonging to $R$. pseudosolanacearum and/or $R$. syzygii subsp. indonesiensis, not to the present $R$. solanacearum species, and only two of them demonstrated successful biocontrol potential in planta. Despite the publication of three patents on the topic, until now no bacteriophage-based product is commercially available. Therefore, there is still much to be done to incorporate valid bacteriophages in an integrated management program to effectively fight bacterial wilt in the field.

Keywords: biological agent, lytic phage, lysogenic phage, treatment, management

\section{INTRODUCTION}

The species Ralstonia solanacearum, R. pseudosolanacearum, and R. syzygii subsp. indonesiensis (Safni et al., 2014) are the causative agents of bacterial wilt (Kelman, 1953; Hayward, 1991), a disease with a worldwide distribution (Elphinstone, 2005; EPPO, 2017). During the last decade, they have been considered the "R. solanacearum species complex" (Fegan and Prior, 2005), still known as $R$. solanacearum, the name that will be maintained in this review. $R$. solanacearum has been traditionally classified in five biovars, five races, and four phylotypes, according to biochemical properties (Hayward, 1964, 1991), host range (Buddenhagen and Kelman, 1964; Hayward, 1991) and molecular characteristics (Fegan and Prior, 2005), respectively (Figure 1). Currently, this pathogen affects more than 400 plant species, including strategic solanaceous crops and ornamental plants. The effects are particularly harmful on potato or tomato because they are staple crops. Harvest losses can reach up to $100 \%$ in banana, $90 \%$ in tomato and potato, $30 \%$ in tobacco and $20 \%$ in peanut (Elphinstone, 2005). Symptoms caused by this plant pathogenic bacterium are progressive wilting of the plant and rotting of potato tubers. $R$. solanacearum has been ranked 
in the second place in the top 10 list of more devastating plant pathogenic bacteria (Mansfield et al., 2012). This pathogen is provided with a wide range of virulence and pathogenicity factors (Schell, 2000; Genin and Denny, 2012; Peeters et al., 2013), a high number of effectors (Poueymiro and Genin, 2009; Deslandes and Genin, 2014) and novel virulence-associated functions (Genin and Denny, 2012; Poueymiro et al., 2014). The bacterium infects the host colonizing the xylem (Vasse et al., 1995), reaching high populations which activate a quorum sensing system with $\mathrm{PhcA}$ as a key transcriptional regulator (Schell, 2000), and eventually causing plant wilting. The pathogen can then return to the environment, where it disseminates mainly through plant material, soil, weeds, and water (Elphinstone et al., 1998; Elphinstone, 2005; López and Biosca, 2005; Álvarez et al., 2010), and can persist in these reservoirs under adverse conditions for long periods by different strategies, retaining pathogenicity (Álvarez et al., 2008, 2010).
The numerous pathogenicity determinants, wide host range and ability to survive of $R$. solanacearum make it difficult the control of the bacterial wilt disease, particularly by chemicals and/or physical treatments, as well as cultural practices. The application of copper compounds and other agrochemicals has a strong environmental impact, and is often related to the appearance of bacterial resistance or even the viable but nonculturable state (Grey and Steck, 2001; Yuliar et al., 2015). Alternatively, numerous biocontrol strategies have been carried out, which also have the advantage of being environmentally friendly. Bacterial wilt biocontrol has been mainly focused on the use of antagonistic microorganisms, usually avirulent mutants of the pathogen and strains of other bacterial species, and also some fungi and bacteriophages (Yuliar et al., 2015; Buttimer et al., 2017).

Advances in biocontrol measures for bacterial wilt include an increasing interest in bacteriophages (viruses specifically infecting bacteria), which are the most abundant microorganisms

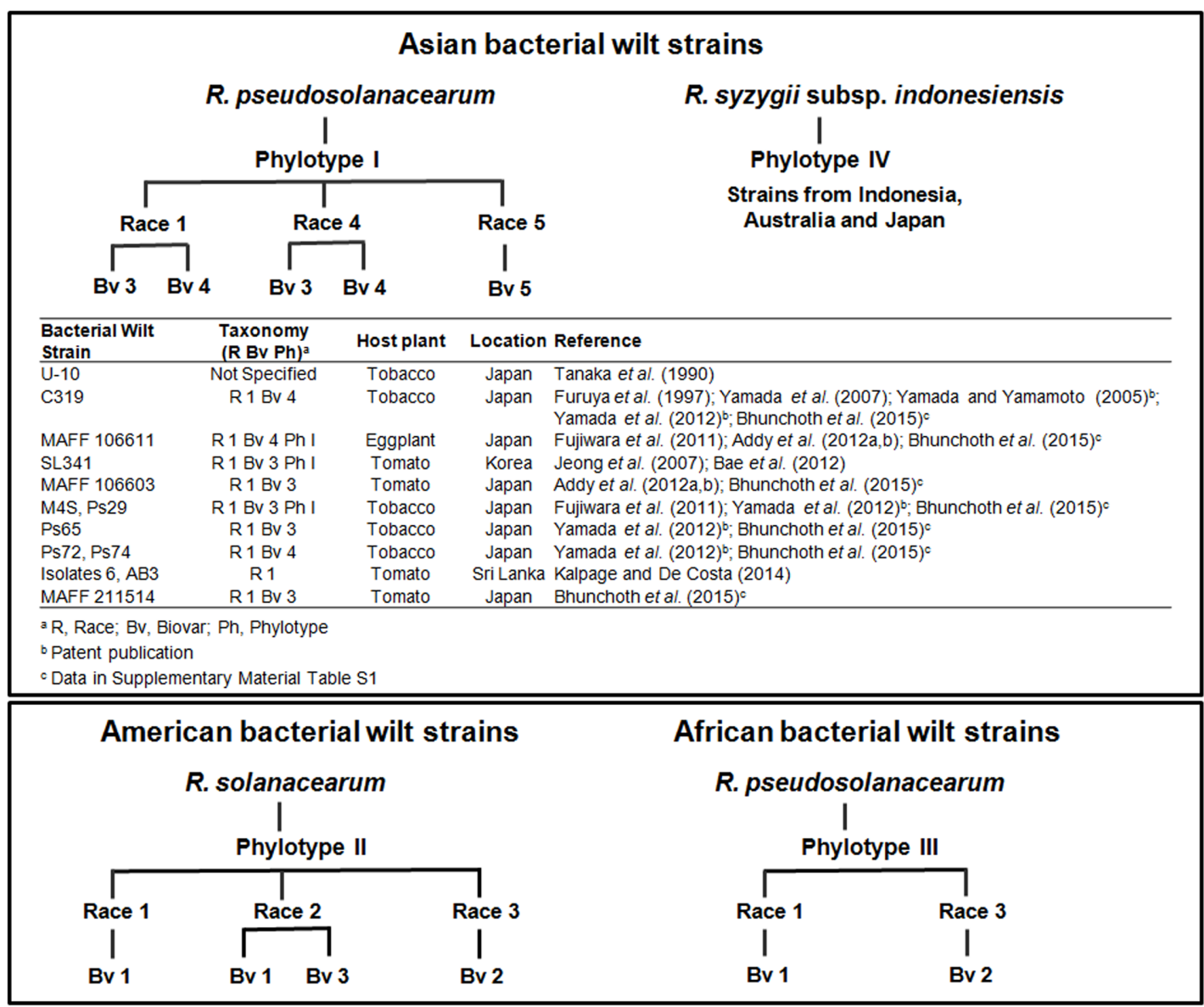

FIGURE 1 | Bacterial wilt strains used to test the biocontrol potential of the bacteriophages in planta. Correspondence among the geographical origin of bacterial wilt strains, the species Ralstonia pseudosolanacearum, R. syzygii subsp. indonesiensis, and present $R$. solanacearum (Safni et al., 2014) (former "R. solanacearum species complex" according to Fegan and Prior, 2005), and previous infraspecific classifications of the species complex in four phylotypes, five races, and five biovars, according to molecular characteristics (Fegan and Prior, 2005), host range (Buddenhagen and Kelman, 1964; Hayward, 1991) and biochemical properties (Hayward, 1964, 1991), respectively. To date, all bacteriophage-based biocontrol assays were performed against Asian bacterial wilt strains, presently not classified as R. solanacearum. 
regulating bacterial populations in the environment. Many of them have a host range restricted to one or few related bacterial species, and consequently, are potential biocontrol agents capable of targeting bacterial pathogens without environmental risk on either the crop to be protected or the surrounding environmental microbiota. According to their life cycle they can be lytic or lysogenic. Lytic phages proliferate and destroy the host bacterial cell, being more effective against the target bacteria, whereas lysogenic phages integrate their genome into the genome of the bacterial host and replicate without destroying the bacterial cell. Thus, bacterial infectious diseases can be treated by the action of phages, a biocontrol method also known as phage therapy. This method can be considered as a promising strategy against bacterial wilt disease (Fujiwara et al., 2011; Bae et al., 2012; Bhunchoth et al., 2015), since it has been successfully applied for controlling some important plant diseases caused by phytopathogenic bacteria (Jones et al., 2007; Balogh et al., 2010; Doffkay et al., 2015; Buttimer et al., 2017).

\section{BACTERIOPHAGE-BASED BACTERIAL WILT BIOCONTROL}

Biocontrol of $R$. solanacearum has been described with either lytic or lysogenic bacteriophages and has been carried out in different ways with variable results (Table 1). Although in most of these cases the isolated phages were active against strains presently not classified as $R$. solanacearum (Figure 1), this nomenclature will be maintained in this review, according to the published works.

Okabe and Goto (1963) reviewed the bacteriophages in relation to plant diseases, with a number of papers concerning the phages of $R$. solanacearum. Thus, a lytic phage named S1 active against three out of 40 strains of the pathogen, and five lysogenic phages affecting different strains, were reported. Attempts to use phages for bacterial wilt control were made, some of them with success. These assays were performed by inoculations with a mixture of the phage and the bacterium, or by previous treatment of plants or seeds with the phage (Okabe and Goto, 1963). The same authors reported that, when tomato or tobacco plants were set in a soil infested with the phagebacterium mixture without successful biocontrol, the phage could be reisolated from the wilted stems (Okabe and Goto, 1963). As a part of an integrated biocontrol treatment, plant inoculations with bacteriophage P4282, isolated from wilted tobacco stems in Japan, were performed (Tanaka et al., 1990). P4282 was added with and without an avirulent strain of the pathogen named M4S. Subsequently, inoculations of the same plants with a virulent strain of the pathogen revealed that the combined treatment of the phage P4282 plus the avirulent bacterial strain M4S was more effective in reducing the incidence and severity of tobacco wilt (Table 1) than the use of the avirulent strain alone (Tanaka et al., 1990).

In addition to phage P4282, there were other lytic bacteriophages with similar infective ability but, with limited host range (Tanaka et al., 1990; Toyoda et al., 1991; Ozawa et al., 2001), and so biocontrol assays in planta were not carried out with them. Yamada et al. (2007) described the isolation of four types of bacteriophages ( $\varphi$ RSL, $\varphi$ RSA, $\varphi$ RSM, and $\varphi$ RSS) that specifically infected strains from soil samples taken in different areas of Japan. These authors performed a morphological and molecular characterization, and some lytic tests with bacterial cultures. Two of them ( $\varphi$ RSA1 and $\varphi$ RSL1) were Myovirus-type bacteriophages, with double-stranded (ds) DNA genomes of very different size (39 and $240 \mathrm{~kb}$, respectively), and phage $\varphi \mathrm{RSA} 1$ having ability to establish lysogenic cycle. The other two ( $\varphi$ RSM1 and $\varphi$ RSS1) were Inovirus-type filamentous bacteriophages (Ff-type). Biocontrol assays were performed by injecting one of the lysogenic bacteriophages ( $\varphi$ RSS1) into the major stem of the tested plants, and it was concluded that this filamentous bacteriophage was not successful for bacterial wilt biocontrol (Yamada et al., 2007) (Table 1). It was then suggested the utility of bacteriophages $\varphi$ RSM 1 and $\varphi$ RSS 1 for molecular biological studies and specific and efficient detection of $R$. solanacearum, as well as the convenience of phages $\varphi$ RSL 1 and $\varphi$ RSA 1 for biocontrol assays of the pathogen in plant crops (Yamada et al., 2007). Another bacteriophage with lytic activity against $R$. solanacearum was isolated in Japan, named $\varphi$ RSB1 (Kawasaki et al., 2009) and classified into the Podoviridae-like family, with dsDNA of approximately $43.0 \mathrm{~kb}$. The host range of phage $\varphi$ RSB 1 included 13 out of $15 R$. solanacearum strains, involving races 1 , 3 , and 4, and biovars 3, 4, and N2 and, therefore, most of them not belonging to the present $R$. solanacearum species (Figure 1). All of these three bacteriophages ( $\varphi$ RSA1, $\varphi$ RSB1, and $\varphi$ RSL1) were later proposed for biocontrol potential in planta (Fujiwara et al., 2011) due to their in vitro lytic activity against a relatively large host range of strains. However, although the activity of bacteriophages $\varphi \mathrm{RSA} 1$ and $\varphi \mathrm{RSB} 1$ (tested separately or in combination) and/or with $\varphi$ RSL1 was effective, soon afterwards populations of resistant $R$. solanacearum cells appeared (Fujiwara et al., 2011). Therefore, in planta biocontrol assays with $\varphi$ RSB1 or $\varphi$ RSA1 were discarded, and only mixtures of them and/or $\varphi$ RSL1, or $\varphi$ RSL1 alone, were considered as biocontrol treatments. The best results were achieved with phage $\varphi$ RSL1, revealing a good potential for bacterial wilt biocontrol (Table 1). Nevertheless, although phage pretreatment of tomato seedlings reduced root colonization by the pathogen and no disease symptoms were observed, there was a remaining coexistence of the bacteriophage and the pathogen (Fujiwara et al., 2011). The phage $\varphi$ RSL1 is considered a large-tailed (jumbo) bacteriophage defining a new lineage of the Myoviridae family, and was isolated from crop fields (Yamada et al., 2007, 2010). The genome size of $\varphi$ RSL1 is $231,255 \mathrm{~kb}$, with a total of 343 orfs grouped into four genomic regions. Phage particles consist of an icosahedral head of $150 \mathrm{~nm}$ in diameter and a long contractile tail that is $138 \mathrm{~nm}$ long and $22.5 \mathrm{~nm}$ wide (Yamada et al., 2010). $\varphi$ RSL1 lytic activity in vitro results in clear plaques with 17 out of 18 bacterial wilt strains of races 1 and 3, and biovars 3 and 4 (Yamada et al., 2010).

A second lytic bacteriophage with a good potential for bacterial wilt biocontrol was PE204, of the Podoviridae family, isolated from a pepper field in Korea (Murugaiyan et al., 2010; Bae et al., 2012). PE204 completely inhibited the incidence of bacterial wilt after simultaneous application with the pathogen in the rhizosphere of tomato plants. It was also found that, 


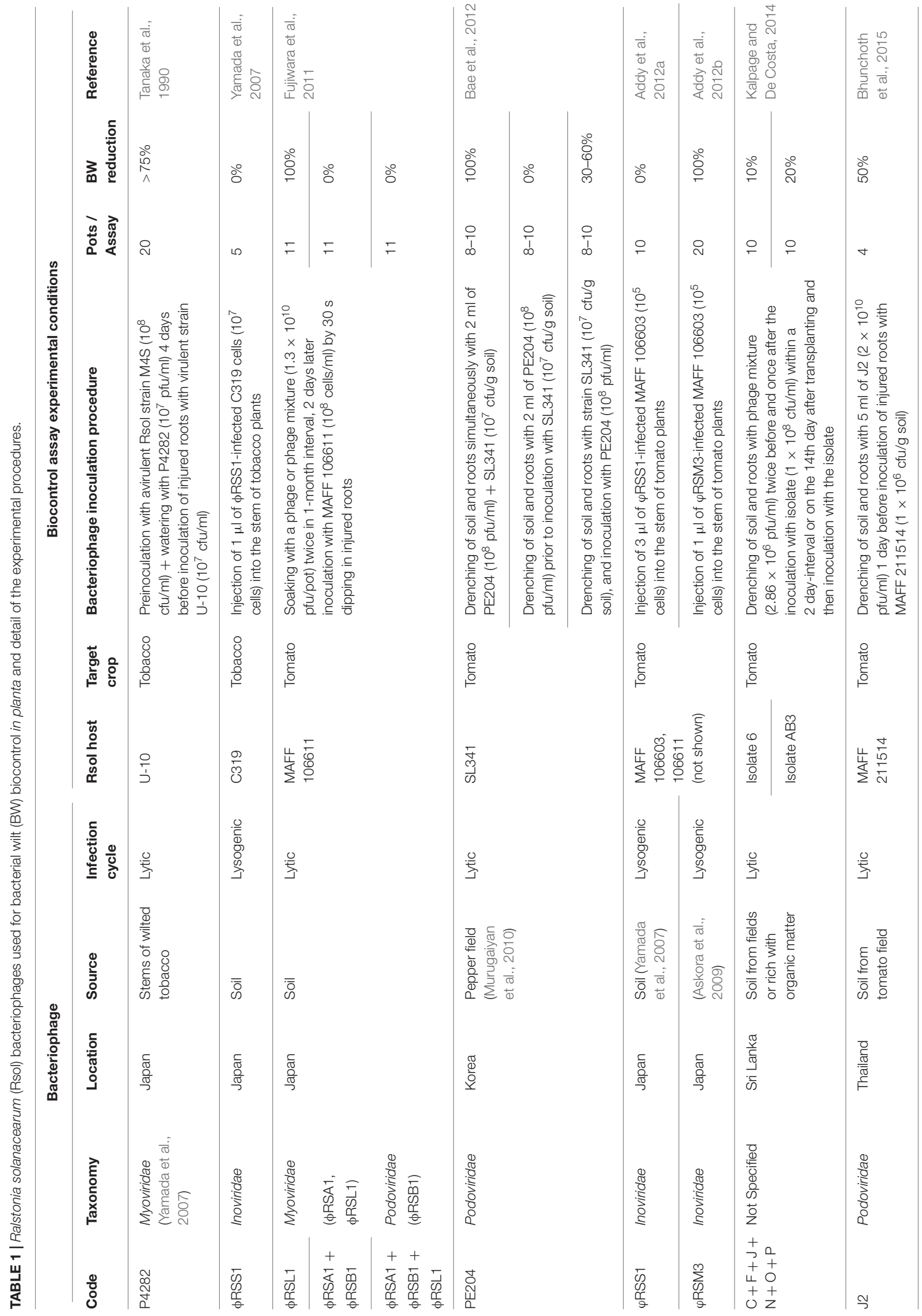


while pretreatment with the phage was ineffective, posttreatment delayed disease development (Bae et al., 2012) (Table 1). Morphological and genomic analysis of PE204 phage particles revealed that it was almost identical to $\varphi \mathrm{RSB} 1$ (Kawasaki et al., 2009), a T7-like phage. PE204 particles had a head of about $60 \mathrm{~nm}$ in diameter and a short tail of 16-20 nm in length. The total PE204 DNA sequence was $21 \mathrm{~kb}$, and included the $\operatorname{orf1} 14$, orf9, $\operatorname{orf17}$, orf22-32, orf37, and $\operatorname{orf3} 38$ of $\varphi \mathrm{RSB} 1$, with a partial genome organization identical to this phage (Bae et al., 2012).

The filamentous bacteriophage $\varphi$ RSS1 (Yamada et al., 2007) was anew assayed to verify the efficacy of bacterial wilt biocontrol (Addy et al., 2012a) (Table 1). In this case, when cells of the pathogen were infected with $\varphi$ RSS1 and injected into tomato plants, an increase in the bacterial virulence was observed, since the infection induced an early expression of the key regulatory $p h c A$ gene, interfering the main $R$. solanacearum quorum sensing system (Addy et al., 2012a). Thus, virulence and pathogenicity factors such as the synthesis of exopolysaccharide and the swimming motility increased in the $\varphi$ RSS1-infected bacterial cells, resulting in early wilting of the host (Addy et al., 2012a). However, filamentous bacteriophages can affect the bacterial wilt pathogen differently. Tomato plants injected with $R$. solanacearum cells infected with $\varphi$ RSM3, another filamentous Inovirus closely related to filamentous phage $\varphi$ RSM 1 (Yamada et al., 2007; Askora et al., 2009), showed no wilting symptoms (Addy et al., 2012b) (Table 1). By contrast, restoration of wilting levels of the pathogen was observed in plants inoculated with bacterial cells infected with the mutant phage $\varphi$ RSM3- $\triangle$ ORF15. It was then suggested a possible role of the orf15 of $\varphi \mathrm{RSM} 3$ on the repression of $p h c A$ gene, resulting in loss of virulence (Addy et al., 2012b). Therefore, filamentous bacteriophages can negatively or positively affect the virulence of $R$. solanacearum according to the presence or absence of a repressor gene in the bacteriophage genome (Addy et al., 2012a,b; Yamada, 2013). In fact, there would be at least two groups of filamentous bacteriophages that differentially affect host cell physiology, including virulence regulatory pathways, presumably by mechanisms that might be similar to those affecting other species of phytopathogenic bacteria infected by their filamentous bacteriophages (Askora and Yamada, 2015).

Subsequently, the characterization of 14 bacteriophages isolated from soil in Thailand, belonging to the Podoviridae and Myoviridae families, revealed that the combination of two podoviruses (J2 and $\varphi$ RSB2) efficiently lysed $R$. solanacearum cells in contaminated soil but, only $\mathrm{J} 2$ treatment prevented disease development in tomato plants (Bhunchoth et al., 2015) (Table 1). The application of mixtures of other six lytic bacteriophages, isolated from soil in Sri Lanka, to the rhizosphere of tomato plants as a soil drench reduced the incidence of bacterial wilt about $10-20 \%$, either by applying bacteriophage mixtures immediately before inoculation with the pathogen, or watering the soil several times with such mixtures (Kalpage and De Costa, 2014) (Table 1).

At present, two bacteriophages ( $\varphi$ RSL1 and PE204) proved to be successful for bacterial wilt biocontrol, as it was observed in assays performed in pots with infected tomato plants treated each time with just one of them (Table 1). However, host range for these phages only included Asian strains of the pathogen, probably belonging to the present $R$. pseudosolanacearum or $R$. syzygii subsp. indonesiensis species (Figure 1).

\section{PATENT LITERATURE ON BACTERIOPHAGE-BASED BACTERIAL WILT BIOCONTROL}

Three patents have been published in relation to bacterial wilt biocontrol, the last of them with international extension in the United States and China. Japanese patent with publication number JP2005278513 describes three types of $R$. solanacearum bacteriophages with lytic activity against the pathogen, which were isolated from soil in Japan. The phages were initially characterized by their genome size and host range, which was assayed against six Japanese strains isolated from tobacco plants, all of them of race 1: M4S, Ps29, and Ps65 of biovar 3, and C319, Ps72, and Ps74 of biovar 4 (Bhunchoth et al., 2015, Supplementary Table S1) and, therefore, all of them belonging to phylotypes I or IV of the former species complex, and presently not $R$. solanacearum (Figure 1). Biocontrol assays were performed against strain C319 by spraying a phage of type 1 or 2 onto tobacco plants or as a soil conditioner (Yamada and Yamamoto, 2005). A second Japanese patent, with publication number JP2007252351 (also published as JP4862154-B2), included a new type of bacteriophage, named $\varphi$ RSA1, with a wider host range with respect to the previous ones. However, although this bacteriophage showed in vitro lytic activity against 15 bacterial strains, the bacterial wilt biocontrol efficacy in planta was not evaluated (Fujie et al., 2007). In a third Japanese patent, with publication number $\mathrm{WO} / 2012 / 147928$, an agent and a method for preventing bacterial wilt disease were developed, consisting of the application of any of the strains M4S, Ps29, Ps65, and Ps74 infected with $\varphi$ RSM1-type filamentous phage or any of the strains C319, Ps72, and Ps74 infected with $\varphi$ RSM3-type filamentous phage, by injection into the plant stems at $10^{5-8}$ cells/g plant. This patent was focused on the prevention of bacterial wilt, since the plants injected with bacterial cells containing the filamentous phages integrated in their genomes showed increased resistance to the pathogen for at least 2 months (Yamada et al., 2012). In spite of the publication of these patents, until now no bacteriophage-based product is commercially available to fight bacterial wilt in the field.

\section{FUTURE PERSPECTIVE}

Further studies on bacteriophage-based bacterial wilt biocontrol methods should focus on biocontrol efficiency under field conditions, a range of susceptible growing 
crops, and the use of bacteriophage mixtures to prevent the appearance of resistant strains of $R$. solanacearum. Phage bioproduction and formulations to be used as biopesticides for a sustainable and environmentally friendly agriculture would be also necessary. A promising approach to increase the efficacy against the bacterial wilt disease would be the incorporation of phages as biocontrol agents that could be combined with other biocontrol strategies in an integrated control program.

\section{REFERENCES}

Addy, H. S., Askora, A., Kawasaki, T., Fujie, M., and Yamada, T. (2012a). The filamentous phage $\varphi$ RSS1 enhances virulence of phytopathogenic Ralstonia solanacearum on tomato. Phytopathology 102, 244-251. doi: 10.1094/PHYTO10-11-0277

Addy, H. S., Askora, A., Kawasaki, T., Fujie, M., and Yamada, T. (2012b). Loss of virulence of the phytopathogen Ralstonia solanacearum through infection by $\varphi$ RSM filamentous phages. Phytopathology 102, 469-477. doi: 10.1094/ PHYTO-11-11-0319-R

Álvarez, B., Biosca, E. G., and López, M. M. (2010). "On the life of Ralstonia solanacearum, a destructive bacterial plant pathogen," in Current Research, Technology and Education Topics in Applied Microbiology and Microbial Biotechnology, ed. A. Méndez-Vilas (Badajoz: Formatex), 267-279.

Álvarez, B., López, M. M., and Biosca, E. G. (2008). Survival strategies and pathogenicity of Ralstonia solanacearum phylotype II subjected to prolonged starvation in environmental water microcosms. Microbiology 154, 3590-3598. doi: 10.1099/mic.0.2008/019448-0

Askora, A., Kawasaki, T., Usami, S., Fujie, M., and Yamada, T. (2009). Host recognition and integration of filamentous phage $\varphi \mathrm{RSM}$ in the phytopathogen, Ralstonia solanacearum. Virology 384, 69-76. doi: 10.1016/j.virol.2008.11.007

Askora, A., and Yamada, T. (2015). Two different evolutionary lines of filamentous phages in Ralstonia solanacearum: their effects on bacterial virulence. Front. Genet. 6:217. doi: 10.3389/fgene.2015.00217

Bae, J. Y., Wu, J., Lee, H. J., Jo, E. J., Murugaiyan, S., Chung, E., et al. (2012). Biocontrol potential of a lytic bacteriophage PE204 against bacterial wilt of tomato. J. Microbiol. Biotechnol. 22, 1613-1620. doi: 10.4014/jmb.1208.08072

Balogh, B., Jones, J. B., Iriarte, F. B., and Momol, M. T. (2010). Phage therapy for plant disease control. Curr. Pharm. Biotechnol. 11, 48-57. doi: 10.2174/ 138920110790725302

Bhunchoth, A., Phironrit, N., Leksomboon, C., Chatchawankanphanich, O., Kotera, S., Narulita, E., et al. (2015). Isolation of Ralstonia solanacearuminfecting bacteriophages from tomato fields in Chiang Mai, Thailand, and their experimental use as biocontrol agents. J. Appl. Microbiol. 118, 1023-1033. doi: $10.1111 /$ jam.12763

Buddenhagen, I. W., and Kelman, A. (1964). Biological and physiological aspects of bacterial wilt caused by Pseudomonas solanacearum. Annu. Rev. Phytopathol. 2, 203-230. doi: 10.1146/annurev.py.02.090164.001223

Buttimer, C., McAuliffe, O., Ross, R. P., Hill, C., O’Mahony, J., and Coffey, A. (2017). Bacteriophages and bacterial plant diseases. Front. Microbiol. 8:34. doi: $10.3389 /$ fmicb.2017.00034

Deslandes, L., and Genin, S. (2014). Opening the Ralstonia solanacearum type III effector tool box: insights into host cell subversion mechanisms. Curr. Opin. Plant Biol. 20, 110-117. doi: 10.1016/j.pbi.2014.05.002

Doffkay, Z., Dömötör, D., Kovács, T., and Rákhely, G. (2015). Bacteriophage therapy against plant, animal and human pathogens. Acta Biol. Szeged. 59, 291-302. doi: 10.3390/v9030050

Elphinstone, J. G. (2005). "The current bacterial wilt situation: a global overview," in Bacterial Wilt Disease and the Ralstonia solanacearum Species Complex, eds C. Allen, P. Prior, and A. C. Hayward (St. Paul, MN: APS Press), 9-28.

Elphinstone, J. G., Stanford, H., and Stead, D. E. (1998). Survival and transmission of Ralstonia solanacearum in aquatic plants of Solanum dulcamara and associated surface water in England. EPPO Bull. 28, 93-94. doi: 10.1111/j.13652338.1998.tb00709.x

\section{AUTHOR CONTRIBUTIONS}

BA and EGB wrote the manuscript.

\section{ACKNOWLEDGMENT}

The authors thank Frontiers Media SA for partial funding of the manuscript, which was also supported by the authors.

EPPO (2017). PQR - EPPO Database on Quarantine Pests. Available at: http://www. eppo.int

Fegan, M., and Prior, P. (2005). "How complex is the "Ralstonia solanacearum species complex"?" in Bacterial Wilt Disease and the Ralstonia solanacearum Species Complex, eds C. Allen, P. Prior, and A. C. Hayward (St. Paul, MN: APS Press), 449-461.

Fujie, M., Yamada, T., and Kawasaki, T. (2007). Ralstonia solanacearum infective bacteriophage. Japanese Patent JP 2007252351. Tokyo: Japan Patent Office.

Fujiwara, A., Fujisawa, M., Hamasaki, R., Kawasaki, T., Fujie, M., and Yamada, T. (2011). Biocontrol of Ralstonia solanacearum by treatment with lytic bacteriophages. Appl. Environ. Microbiol. 77, 4155-4162. doi: 10.1128/AEM. 02847-10

Furuya, N., Yamasaki, S., Nishioka, M., Shiraishi, I., Iiyama, K., and Matsuyama, N. (1997). Antimicrobial activities of Pseudomonads against plant pathogenic organisms and efficacy of Pseudomonas aeruginosa ATCC7700 against bacterial wilt of tomato. Ann. Phytopathol. Soc. Japan 63, 417-424. doi: 10.3186/ jjphytopath.63.417

Genin, S., and Denny, T. P. (2012). Pathogenomics of the Ralstonia solanacearum species complex. Annu. Rev. Phytopathol. 50, 67-89. doi: 10.1146/annurevphyto-081211-173000

Grey, B. E., and Steck, T. R. (2001). The viable but nonculturable state of Ralstonia solanacearum may be involved in long-term survival and plant infection. Appl. Environ. Microbiol. 67, 3866-3872. doi: 10.1128/AEM.67.9.3866-3872.2001

Hayward, A. C. (1964). Characteristics of Pseudomonas solanacearum. J. Appl. Bacteriol. 27, 265-277. doi: 10.1111/j.1365-2672.1964.tb04912.x

Hayward, A. C. (1991). Biology and epidemiology of bacterial wilt caused by Pseudomonas solanacearum. Annu. Rev. Phytopathol. 29, 65-87. doi: 10.1146/ annurev.py.29.090191.000433

Jeong, Y., Kim, J., Kang, Y., Lee, S., and Hwang, I. (2007). Genetic diversity and distribution of Korean isolates of Ralstonia solanacearum. Plant Dis. 91, 1277-1287. doi: 10.1094/PDIS-91-10-1277

Jones, J. B., Jackson, L. E., Balogh, B., Obradovic, A., Iriarte, F. B., and Momol, M. T. (2007). Bacteriophages for plant disease control. Annu. Rev. Phytopathol. 45, 245-262. doi: 10.1146/annurev.phyto.45.062806.094411

Kalpage, M. D., and De Costa, D. M. (2014). Isolation of bacteriophages and determination of their efficiency in controlling Ralstonia solanacearum causing bacterial wilt of tomato. Trop. Agric. Res. 26, 140-151. doi: 10.4038/tar.v26i1. 8079

Kawasaki, T., Shimizu, M., Satsuma, H., Fujiwara, A., Fujie, M., Usami, S., et al. (2009). Genomic characterization of Ralstonia solanacearum phage $\varphi$ RSB1, a T7-like wide-host-range phage. J. Bacteriol. 191, 422-427. doi: 10.1128/JB. 01263-08

Kelman, A. (1953). The Bacterial Wilt Caused by Pseudomonas solanacearum. A Literature Review and Bibliography. Raleigh, NC: North Carolina State College, 1-194.

López, M. M., and Biosca, E. G. (2005). "Potato bacterial wilt management: new prospects for an old problem," in Bacterial Wilt Disease and the Ralstonia solanacearum Species Complex, eds C. Allen, P. Prior, and A. C. Hayward (St. Paul, MN: APS Press), 205-224.

Mansfield, J., Genin, S., Magori, S., Citovsky, V., Sriariyanum, M., Ronald, P., et al. (2012). Top 10 plant pathogenic bacteria in molecular plant pathology. Mol. Plant Pathol. 13, 614-629. doi: 10.1111/j.1364-3703.2012.00804.x

Murugaiyan, S., Bae, J. Y., Wu, J., Lee, S. D., Um, H. Y., Choi, H. K., et al. (2010). Characterization of filamentous bacteriophage PE226 infecting 
Ralstonia solanacearum strains. J. Appl. Microbiol. 110, 296-303. doi: 10.1111/j. 1365-2672.2010.04882.x

Okabe, N., and Goto, M. (1963). Bacteriophages of plant pathogens. Annu. Rev. Phytopathol. 1, 397-418. doi: 10.1146/annurev.py.01.090163.002145

Ozawa, H., Tanaka, H., Ichinose, Y., Shiraishi, T., and Yamada, T. (2001). Bacteriophage P4282, a parasite of Ralstonia solanacearum, encodes a bacteriolytic protein important for lytic infection of its host. Mol. Genet. Genomics 265, 95-101. doi: 10.1007/s004380000389

Peeters, N., Carrère, S., Anisimova, M., Plener, L., Cazalé, A. C., and Genin, S. (2013). Repertoire, unified nomenclature and evolution of the type III effector gene set in the Ralstonia solanacearum species complex. BMC Genomics 14:859. doi: 10.1186/1471-2164-14-859

Poueymiro, M., Cazalé, A. C., François, J. M., Parrou, J. L., Peeters, N., and Genin, S. (2014). A Ralstonia solanacearum type III effector directs the production of the plant signal metabolite trehalose-6-phosphate. mBio 5:e02065-14. doi: 10.1128/ mBio.02065-14

Poueymiro, M., and Genin, S. (2009). Secreted proteins from Ralstonia solanacearum: a hundred tricks to kill a plant. Curr. Opin. Microbiol. 12, 44-52. doi: 10.1016/j.mib.2008.11.008

Safni, I., Cleenwerck, I., De Vos, P., Fegan, M., Sly, L., and Kappler, U. (2014). Polyphasic taxonomic revision of the Ralstonia solanacearum species complex: proposal to emend the descriptions of Ralstonia solanacearum and Ralstonia syzygii and reclassify current $R$. syzygii strains as Ralstonia syzygii subsp. syzygii subsp. nov., $R$. solanacearum phylotype IV strains as Ralstonia syzygii subsp. indonesiensis subsp. nov., banana blood disease bacterium strains as Ralstonia syzygii subsp. celebesensis subsp. nov. and R. solanacearum phylotype I and III strains as Ralstonia pseudosolanacearum sp. nov. Int. J. Syst. Evol. Microbiol. 64, 3087-3103. doi: 10.1099/ijs.0.066712-0

Schell, M. A. (2000). Control of virulence and pathogenicity genes of Ralstonia solanacearum by an elaborate sensory network. Annu. Rev. Phytopathol. 38, 263-292. doi: 10.1146/annurev.phyto.38.1.263

Tanaka, H., Negishi, H., and Maeda, H. (1990). Control of tobacco bacterial wilt by an avirulent strain of Pseudomonas solanacearum M4S and its bacteriophage. Ann. Phytopathol. Soc. Japan 56, 243-246. doi: 10.3186/jjphytopath.56.243

Toyoda, H., Kakutani, K., Ikeda, S., Goto, S., Tanaka, H., and Ouchi, S. (1991). Characterization of deoxyribonucleic acid of virulent bacteriophage and its infectivity to host bacteria, Pseudomonas solanacearum. J. Phytopathol. 131, 11-21. doi: 10.1111/j.1439-0434.1991.tb04566.x

Vasse, J., Frey, P., and Trigalet, A. (1995). Microscopic studies of intercellular infection and protoxylem invasion of tomato roots by Pseudomonas solanacearum. Mol. Plant Microbe Interact. 8, 241-251. doi: 10.1094/MPMI-80241

Yamada, T. (2013). Filamentous phages of Ralstonia solanacearum: double-edged swords for pathogenic bacteria. Front. Microbiol. 4:325. doi: 10.3389/fmicb. 2013.00325

Yamada, T., Fujie, M., and Kawasaki, T. (2012). Agent for preventing bacterial wilt disease, and method for preventing bacterial wilt disease. Japanese Patent WO/2012/147928. Tokyo: Japan Patent Office.

Yamada, T., Kawasaki, T., Nagata, S., Fujiwara, A., Usami, S., and Fujie, M. (2007). New bacteriophages that infect the phytopathogen Ralstonia solanacearum. Microbiology 153, 2630-2639. doi: 10.1099/mic.0.2006/001453-0

Yamada, T., Satoh, S., Ishikawa, H., Fujiwara, A., Kawasaki, T., Fujie, M., et al. (2010). A jumbo phage infecting the phytopathogen Ralstonia solanacearum defines a new lineage of the Myoviridae family. Virology 398, 135-147. doi: 10.1016/j.virol.2009.11.043

Yamada, T., and Yamamoto, K. (2005). Bacteriophage having bacteriolytic action on Ralstonia solanacearum. Japanese Patent JP2005278513. Tokyo: Japan Patent Office.

Yuliar, Nion, Y. A., and Toyota, K. (2015). Recent trends in control methods for bacterial wilt diseases caused by Ralstonia solanacearum. Microbes Environ. 30, 1-11. doi: 10.1264/jsme2.ME14144

Conflict of Interest Statement: The authors declare that the research was conducted in the absence of any commercial or financial relationships that could be construed as a potential conflict of interest.

Copyright (C) 2017 Álvarez and Biosca. This is an open-access article distributed under the terms of the Creative Commons Attribution License (CC BY). The use, distribution or reproduction in other forums is permitted, provided the original author(s) or licensor are credited and that the original publication in this journal is cited, in accordance with accepted academic practice. No use, distribution or reproduction is permitted which does not comply with these terms. 